Hanna Strużyna

Andrzej Strużyna

Uniwersytet Opolski

\title{
Wyjątkowość doświadczenia śmierci w artystycznych grach wideo
}

Wprawdzie powaga i doniosłość śmierci na przestrzeni wieków ulegała licznym zmianom [por. Ariès 2011], jednakże refleksja nad znaczeniem kresu życia nadal stanowi jedno z najważniejszych zagadnień filozoficznych, którego odblask uobecnia się w dziełach kultury. W przypadku gier wideo motyw śmierci doświadczany jest inaczej, aniżeli w innych dziedzinach sztuki. Medium ergodyczne umożliwia „przeżycie” śmierci w wielu kontekstach, które najczęściej sprowadzane są do dwóch sytuacji: pokonania rywala i śmierci własnego awatara.

$\mathrm{W}$ artykule pojęcie śmierci awatara zostało ujęte w szerokim kontekście kulturowym, co nie wyczerpuje podejmowanego tematu. Kluczową kwestią poruszoną w niniejszym tekście jest wyjątkowość reprezentacji śmierci w artystycznych grach wideo ${ }^{1}$. Analiza trzech przykładów sztuki gier wideo została poprzedzona przywołaniem kulturowych kontekstów śmierci we współczesności oraz refleksją nad podstawowymi sposobami uobecniania się śmierci w nieartystycznych grach wideo. Zarysowany szeroki kontekst zagadnienia otwiera pole dla dalszych analiz.

Używanego w tekście pojęcia śmierci awatara nie należy rozumieć dosłownie. Wirtualny charakter bohatera gry wideo określa także specyfikę jego śmierci. Tak jak postać gry jest niefizykalna i nieuchwytna przez wszystkie zmysły (interakcja gracza

1 Przez pojęcie artystycznych gier wideo rozumiemy konkretne, pojedyncze dzieła przynależne do sztuki gier wideo. Jednocześnie zaznaczamy, że w artykule stosujemy pojęcia gry wideo i gry komputerowe zamiennie. Mając świadomość ich złożoności pod względem definicyjnym, uważamy, że pojęcia te są względem siebie komplementarne. 
Z wirtualnym awatarem jest pośrednia i angażuje tylko część sensorium człowieka), tak i wirtualna śmierć doświadczana jest jako niepełna i podlegająca innej logice niż kulturowo rozumiana śmierć jako moment liminalny życia człowieka. Przejawia się to w postawie gracza, który przyzwyczaił się do traktowania śmierci postaci obserwowanych na ekranie jako zjawiska naturalnego, ponieważ zdaje sobie sprawę z umowności rozgrywki oraz zasad gry, które definiują wirtualną śmierć inaczej, niż nakazywałby społeczny i obrzędowy wymiar śmierci. Zwłaszcza że dla graczy przestrzeń wirtualna doświadczana jest niejednoznacznie, czyli jednocześnie realnie i fikcyjnie. Jak wskazywał Espen Aarseth [2013], gry wideo nie zostały stworzone w celu odwzorowania świata pozagrowego, jednakże cechują się zrozumiałą, immanentną logiką [s. 491].

Śmierć w przestrzeni wirtualnej posiada inne znaczenie niż śmierć rzeczywista. Tworzy granicę temporalną w akcji gry, sprawiając, że gracz zostaje chwilowo wyeliminowany ze świata gry. Nawet gdy separacja oznacza koniec rozgrywki, to gracz zawsze może ją rozpocząć ponownie, tym razem bogatszy w doświadczenie i wiedzę o świecie gry. Mimo to śmierć awatara posiada wymiar symboliczny i niezaprzeczalnie angażuje gracza emocjonalnie.

\section{Zmiana znaczenia śmierci we współczesności}

Śmierć to jeden z najczęściej pojawiających się motywów w sztuce. Akt umierania, zatem swoiste „wydarzenie” śmierci, zawsze fascynował ludzkość, ponieważ stawiał przed ludźmi mnogość fundamentalnych pytań o znaczenie nie tylko samego kresu życia, ale również racji bytu człowieka. Gloryfikacja śmierci związana jest z tym, co nieznane i niedostępne, ponieważ „człowiek nie ma żadnego bezpośredniego doświadczenia śmierci” [Czarny 1999, 25]. Bogactwo kulturowego wymiaru kresu życia przejawia się w licznych dziedzinach kultury. Jak stwierdził Gérard Lenne [2002], w kinematografii światowej śmierć stanowi jeden z trzech najczęściej pojawiających się motywów obok pieniędzy i seksu [s. 223]. Zdaniem francuskiego badacza to śmierć jest w największym stopniu tabuizowana, co z kolei sprawia, że staje się obiektem fascynacji. Zauważyć należy, że myśl Lennego wpisuje się w refleksję Philipe’a Arièsa dotyczącą nowego modelu umierania, który określił mianem odwróconej śmierci [1993, 228-229]. Ariès spostrzegł, że śmierć od XVIII wieku była stopniowo wyrzucana z rzeczywistości społecznej, czego efektem było uznanie jej za nieczystą i nieprzyzwoitą, zatem wymagającą dyskrecji [1993, 201]. Zwracał na to uwagę również Geoffrey Gorer, który porównał nieprzyzwoitość śmierci z obscenicznością seksu i stwierdził, że współcześnie zauważalna jest tendencja do traktowania śmierci jako pornografii. Śmierć utraciła swoją tajemniczość z powodu dowiedzenia naturalności jej procesu [Gorer 1955, 50]. Wskutek tego postrzegalna jest 
dwoistość ontycznego pojmowania fenomenu śmierci: w znaczeniu materialności ciała ludzkiego, która określa naturalność ograniczonego czasu życia, oraz psychicznego uwarunkowania stosunku człowieka do życia, który przejawia się w odrzuceniu naturalności śmierci i traktowaniu jej jako abstrakcyjnej, niepojętej [Czarny 1999, 28]. Dlatego obserwowalny jest rozdźwięk pomiędzy kulturowym znaczeniem śmierci a faktyczną wiedzą współczesnego człowieka. Inaczej ujmując, kulturowe dziedzictwo znaczeń i symboli związanych z aktem umierania stanowi obiekt fascynacji, będącej swoistym substytutem doświadczenia zjawiska śmierci czy też jej „zastępczą gratyfikacją” [Gorer 1955, 52], która przejawia się w różnych dziedzinach kultury i sztuki, w tym też w kulturze popularnej.

\section{Śmierć w grach wideo}

Problematyka występowania motywu śmierci w grach komputerowych jest niejednoznaczna. Wynika to z faktu odmiennej specyfiki wirtualnej śmierci, którą należy rozpatrywać na dwóch płaszczyznach: pierwszoplanowej (śmierci awatara gracza) i drugoplanowej (śmierci innych postaci gry). Co istotne, występujące relacje na linii użytkownik - świat przedstawiony (którego częścią jest także awatar gracza) są zależne od wielu czynników, a w szczególności kontekstu, jaki narzucają rozwiązania formalne gry. Inne znaczenie posiada śmierć w grach sieciowych, aniżeli w gatunkach skierowanych do pojedynczego użytkownika. Tym bardziej, gdy uświadomimy sobie, że postaci w grze nie muszą być wizualizowane w formie humanoidalnej, dlatego też pojęcia śmierci w grach wideo nie należy ujmować w kategoriach eschatologicznych, chyba że kontekst gry do takiego ujęcia prowokuje.

\section{Śmierć własnego awatara}

Śmierć sterowanego przez gracza awatara zwykle stanowi nagłe przerwanie rozgrywki. Można postawić ogólną tezę, że celem gry jest możliwie jak najdłuższe uniknięcie ostatecznej śmierci. W przypadku gier nieposiadających możliwości zapisu stanu gry np. Super Mario Bros. [Nintendo 1985], Contra [Konami 1987] czy Battle City [Namco 1985] gracz zachęcany jest do skutecznego pokonywania kolejnych poziomów gry poprzez punktację, która określa jego prestiż. We wspomnianych grach awatar posiada wiele żyć, dlatego śmierć nie ma niepodzielnego, absolutnego charakteru. Jednakże skończenie się liczby żyć jest istotnym momentem rozgrywki, ponieważ umożliwia ewaluację działań gracza, co jednocześnie zachęca go do poprawy wyniku [por. Majkowski 2011, 99]. Choć pośrednim celem rozgrywki jest unikanie śmierci awatara, paradoksalnie jej nastąpienie posiada ważne znaczenie dla podtrzymywania zainteresowania grą. 
W przypadku gier z możliwością zapisu i odczytania stanu gry, jak np. w seriach The Elder Scrolls, Medal of Honor czy Grand Theft Auto, śmierć awatara przerywa rozgrywkę, jednak sama zabawa gracza się nie kończy, ponieważ możliwość wczytania zapisanego stanu gry pozwala spróbować jeszcze raz zmierzyć się z wyzwaniem. W tym kontekście śmierć awatara jest czymś niepożądanym. Nie prowadzi, w odróżnieniu od wspomnianych wcześniej gier, do podsumowania jego działań, choć konstrukcja gry nadal zachęca do przezwyciężenia niepowodzeń (czyli śmierci awatara). Inaczej prezentują się te formy rozgrywki uniemożliwiające wczytanie stanu gry, w których śmierć stanowi definitywny koniec. Rozwiązanie takie zastosowano w grach Diablo II [Blizzard North 2000] i Diablo III [Blizzard Entertainment 2012], co ma na celu podtrzymanie zainteresowania grą wśród doświadczonych graczy. Śmierć w trybie „zawodowca” (Diablo II) i „hardcore” (Diablo III) buduje napięcie rozgrywki, ponieważ gracz posiada tylko jedną szansę na ukończenie gry, co jednocześnie frustruje użytkowników przyzwyczajonych do poczucia posiadania kontroli nad awatarem i rozgrywką.

Powyższą skrótową charakterystykę należy dopełnić jeszcze o gry komputerowe, które wyróżniają się swoim instrumentalnym traktowaniem śmierci awatara. Takimi ewenementami są m.in. Planescape: Torment [Black Isle Studios 1999] czy Might and Magic IX [New World Computing 2002], ponieważ śmierć bohatera lub drużyny rozwija wątek fabularny. Twórcy wspomnianych gier zastosowali innowacyjne rozwiązania śmierci awatara, dzięki czemu przynajmniej w pewnej części przypadków nie kończy się ona konwencjonalnie (tj. komunikatem o konieczności wczytania zapisanego stanu gry). Mimo to obserwowana na ekranie śmierć bohatera nadal jest względna, a do tego nie oznacza końca rozgrywki. Awatar umiera, jednak gra toczy się dalej. Śmierć stanowi przejście do kolejnego etapu i nie stanowi ona przeszkody w powrocie do świata gry.

Interesujące są także te zmiany znaczenia śmierci w grach wideo, które tworzą pomost pomiędzy kolejnymi rozgrywkami. Takim przykładem jest Rogue Legacy [Cellar Door Games 2013]. W sytuacji śmierci awatara rozgrywka nie zostaje zakończona, lecz udostępnia nowe możliwości. Mianowicie gracz może kontynuować grę, poruszając się wybranym potomkiem dotychczasowego awatara. Tytułowe dziedzictwo to nic innego jak geny, a dokładniej uwarunkowane genetycznie wady (np. karłowatość, wady wzroku, daltonizm). Gra przewartościowuje znaczenie protagonisty, który w większości gier wideo przedstawiany jest stereotypowo jako pełnosprawny bohater. Wprowadza także osobliwą logikę śmierci, która podkreśla ciągłość prowadzonej rozgrywki pomimo tego, że była przerwana śmiercią awatara.

O tym, że śmierci wirtualnej nie bierze się na poważnie, świadczą także praktyki graczy w serii The Sims. Jak stwierdził Piotr Sterczewski, „sami gracze często czerpią 
przewrotną przyjemność z czegoś uznawanego »oficjalnie« w ramach gry za porażkę - o czym doskonale wie każdy, kto wyciągnął kiedyś swojemu Simowi drabinkę z basenu. Współcześnie - dzięki popularyzacji nagrań z cudzej rozgrywki - odgrywanie tego typu porażek zyskuje też urok spektaklu” [Sterczewski 2016]. Bardzo często zabijanie Simów było celowe, służyło np. stworzeniu prywatnego cmentarza na posesji (co posiada potwierdzenie w praktykach jednego z autorów artykułu). W tym przypadku śmierć awatara jest tylko środkiem do osiągnięcia celu, przez co partykularnie zabijany Sim traci swą podmiotowość. Wirtualna śmierć jest w tym zakresie rozumiana jako coś naturalnego, wręcz oczekiwanego. Choć przyznać należy, że późniejsze gry $\mathrm{z}$ serii The Sims wprowadziły proces starzenia się Simów i w efekcie ich śmierć była czymś, co gracz starał się możliwie jak najbardziej odsunąć w czasie (wstrzymanie procesu starzenia pomagały odpowiednie przedmioty). Również ten intrygujący sposób zmiany kontekstu śmierci w grze komputerowej dowodzi wieloznaczności i złożoności zagadnienia śmierci w przestrzeni wirtualnej.

\section{Śmierć innych postaci gry}

W zależności od gatunku gry wideo, śmierć awatara może posiadać odrębne znaczenia. W przypadku turniejowych FPS, jak Quake III: Arena czy Unreal Tournament [id Software 1999], unikanie śmierci oraz eliminowanie przeciwników wpływa bezpośrednio na wynik gry. Punktowanym działaniem gracza jest pokonywanie przeciwników, choć nadmienić należy, że w pewnych rodzajach rozgrywki (np. „zdobądź flagę”) zabijanie awatarów nie przekłada się na ostateczny wynik gry. Śmierć w turniejowych grach wideo posiada inny wymiar semiotyczny, w pewnym sensie stanowi efekt uboczny rywalizacji pomiędzy graczami. Pytanie, jakie należy zadać, jest następujące: w jaki sposób została w grach z gatunku FPS ukazana przemoc? Jest ono istotne, ponieważ realistyczne ukazanie przemocy i umierania, jak w grach o tematyce wojennej (Medal of Honor), posiada odmienną logikę: w tych grach zabijanie przeciwników niejednokrotnie jest nieuniknione, ponieważ wykreowana sytuacja (zatem kontekst gry) wprowadza gracza w poczucie konieczności własnej obrony. Z kolei w grach turniejowych funkcjonuje odmienne kontinuum życia i śmierci: odebranie życia to uzyskany lub stracony punkt na liście rankingowej, a rozgrywka trwa, dopóki reguły gry na to pozwalają. Gracz nie ma na celu obrony, lecz zwycięstwo zgodnie z zasadami gry - a zatem poprzez pokonanie rywali.

Pragnieniem współczesnego człowieka, jak stwierdza Zygmunt Bauman, jest kolekcjonowanie przeżyć $[1995,85]$, dlatego nie powinien dziwić fakt, że największą popularność posiadają gry, których rozgrywka opiera się na walce. Dlatego „przemocy” wirtual- 
nej nie należy traktować w dosłownym znaczeniu tych pojęć, ponieważ śmierć awatara funkcjonuje bardziej jako cząstka reguł gry [por. Aarseth 2013, 491; Juul, 2011], a samo sformułowanie „śmierci” należy w tym przypadku pojmować metaforycznie. Istotne w tej sprawie jest stwierdzenie Waldemara Kuligowskiego i Piotra Zwierzchowskiego, którzy uznają, że śmierć w grach wideo jest po prostu normą, ponieważ jej „wydarzenie” nie wywołuje skandalu, lecz ma być widowiskowa i służyć rozrywce [2004, 7-9].

\section{Odmienność doświadczenia śmierci w artystycznych grach wideo}

Zarysowana różnorodność widowiska śmierci występującego w grach wideo jest tylko wycinkiem znaczeń, jakie są nadawane przez kontekst świata przedstawionego gry. Wzbogaceniem tej rozmaitości są artystyczne sposoby zaadaptowania medium gry komputerowej, które często na przekór przyzwyczajeniom graczy starają się wykraczać poza utarte konwencje, sugerować nowe znaczenia rozgrywki i fabuły, a także pogłębiać doświadczenia użytkowników. Jako przykłady posłużą trzy produkcje z nurtu gier niezależnych: Passage [Rohrer 2007], The Graveyard [Tale of Tales 2008] oraz Queers in Love at the End of the World [Anthropy 2013].

Interesujące są zbieżności, jakie odnaleźć można już na pierwszy rzut oka w strukturach tych trzech gier. Łączy je krótki czas rozgrywki (mniej niż dziesięć minut), podejmowana tematyka kresu życia, skupienie siły oddziaływania gry na emocjach odbiorcy, a także sugestywne zachęcenie gracza do refleksji. Poza tymi aspektami gry są radykalnie odmienne, wykorzystują inne rozwiązania formalne i odwołują się do osobnych estetyk gier komputerowych.

\section{Passage}

Tytuł gry Passage [Rohrer 2007] zapowiada ramy narracyjne, które w skrócie określić można mianem „przejścia” przez życie. Obraz gry ukazany został w tzw. perspektywie side-scroll, która w grach $\mathrm{z}$ lat 80. ubiegłego wieku służyła przedstawianiu swoistego kontinuum akcji i upływającego czasu zgodnie z kierunkiem rozciągającym przestrzeń gry w prawą stronę. Gracz przyzwyczajony w grach platformowych do ograniczonej struktury planszy może poczuć się zagubiony w nieskończonej, labiryntowej przestrzeni gry. Zmiana konwencji gry wymusza na użytkowniku odnalezienie sensu i celu rozgrywki oraz zawartych w niej znaczeń.

Passage można potraktować jako zamkniętą w miniaturowej formie alegorię życia człowieka. Rozgrywka toczy się synchronicznie do upływającego czasu, który determinuje sposób postrzegania świata przedstawionego. W toku rozgrywki zmienia się relacja awatara do otaczającej go przestrzeni: na początku gry świat bohatera wybiega daleko 
w przyszłość, a z biegiem czasu ta zależność się odwraca - im starsza postać, tym bardziej jego świat zawiera się w jego przeszłości. Wraz z przechodzeniem gry użytkownik otrzymuje punkty, które znajdują się w tym samym miejscu ekranu, co licznik upływającego czasu w grze Super Mario Bros. Można to potraktować jako ironiczną trawestację reguł: w Mario gracze spieszyli przez planszę, ponieważ koniec czasu oznaczał śmierć awatara, której należy za wszelką cenę uniknąć. W Passage licznik (punktów, nie czasu) wzrasta wraz z podążaniem w kierunku zakładanego końca gry, co można zinterpretować w kategorii rozwoju awatara w miarę zdobywanego doświadczenia życiowego. Jednak nie odnajdziemy nigdzie na mapie gry przejścia do kolejnego poziomu gry, ponieważ - zupełnie jak w życiu - nie da się śmierci uniknąć. Tak jak śmierć nadaje sens ludzkiemu istnieniu, tak w grze stanowi jej najważniejszy element.

Gracz ma możliwość przejść przez życie samotnie lub wspólnie z ukochaną osobą. Wizja autora nie wartościuje jednej możliwości ponad drugą. Wprawdzie można odnieść wrażenie, że ze względu na ułatwioną możliwość spotkania kobiecego awatara Rohrer implikuje w swoją grę romantyczny obraz miłości jedynej na całe życie, jednakże gra oferuje bogactwo znaczeń, które wytwarzane są wraz z prowadzeniem rozgrywki. Wyraża się w tym performatywny charakter rozgrywki, ponieważ gracz posiada szerokie pole możliwości stworzenia audiowizualnej narracji o człowieku. Grę można przejść w linii prostej, wówczas nie spotyka się na drodze żadnych przeszkód. Inną opcją jest zejście w labirynt, który posiada ograniczenia, jednak jego atutem są przedmioty umożliwiające przedłużenie rozgrywki. Dlatego gra nie posiada jednej fabuły, lecz oferuje użytkownikowi stworzenie własnego, niepowtarzalnego doświadczenia gry. Passage wprowadza gracza w momentami radosną rozgrywkę, z czasem przeradzającą się w nostalgiczną opowieść, która prowokuje do rozważań nad życiem, przemijaniem i śmiercią.

\section{The Graveyard}

Podstawowym elementem wyróżniającym The Graveyard [Tale of Tales 2008] od pozostałych analizowanych artystycznych gier wideo jest ujęcie świata gry w obrazie trójwymiarowym. Przestrzeń gry, jak wskazuje tytuł, jest umiejscowiona na cmentarzu ograniczonym do jednej alejki oraz fragmentu placu okalającego cmentarną kaplicę. Kolorystykę grafiki sprowadzono do czerni i bieli, co buduje melancholijny nastrój gry. Gra dostępna jest w wersji pełnej oraz demonstracyjnej, jednakże sposób skonfigurowania rozgrywki sprawia, że choć są one ze sobą związane, to stanowią dwa autonomiczne utwory.

Podzielenie kilkuminutowej gry na dwie wersje wydaje się irracjonalne, jednak twórcy nadają nowe znaczenie tej coraz rzadziej stosowanej praktyce wydawniczej. 
Wersja demonstracyjna The Graveyard nie ma na celu zainteresowania gracza produkcją poprzez prezentację akcji gry lub mechaniki rozgrywki jak w przypadku typowego dema. Tym, co najbardziej intryguje w wersji demonstracyjnej, jest melancholijna fabuła, która daje wrażenie skrywania przed graczem tajemnicy.

Gracz steruje postacią starszej kobiety, co samo w sobie świadczy o wyjściu twórców poza schemat kreowania awatarów jako postaci sprawnych, młodych i pięknych. Gra skonstruowana została w taki sposób, aby zmusić gracza do obserwacji niezgrabnych ruchów bohaterki, która z trudem przemierza cmentarz, a także - w czasie trwania piosenki - przypatrywania się jej zmęczonej, pokrytej zmarszczkami twarzy. Twórcy świadomie igrają z cierpliwością gracza i jego przyzwyczajeniami, również natury estetycznej. Centralnym momentem rozgrywki jest utwór muzyczny, który posiada odmienne znaczenie w obu wersjach gry. W wersji demonstracyjnej piosenka jest najważniejszym wydarzeniem i można ją potraktować jako nostalgiczny wywód głównej bohaterki odwiedzającej groby bliskich. Tekst utworu wydaje się tokiem myśli starszej kobiety, która przywołuje wspomnienia związane ze zmarłymi. W słowach tych wyczuć można z jednej strony tęsknotę, z drugiej zaś melancholię bohaterki prowadzącą refleksję nad przemijaniem. Z kolei w pełnej wersji następuje znacząca zmiana, która odstawia utwór na drugi plan. Pierwszoplanowym wydarzeniem staje się nagła i niespodziewana śmierć bohaterki.

Wydarzenie śmierci w The Graveyard otwiera nowe pola znaczeń, gdzie dwie wersje rozgrywki postawione są w drastycznym kontraście ruchu oraz bezruchu awatara, które sprowadzić można do opozycji aktywne/bierne, interaktywne/nieinteraktywne, żywe/martwe. Wraz ze śmiercią bohaterki gracz traci możliwości interakcji; może trwać przy zmarłym awatarze lub wyłączyć grę. Śmierć awatara jest definitywna, co oznacza, że nie ma możliwości poprawy wyniku gry. Gracz doświadcza własnej bezradności względem powagi i nieusuwalności śmierci. Tekst piosenki traci swoje znaczenie, jakie miał w wersji demonstracyjnej (refleksji bohaterki), a zyskuje nowe - utwór stanowi muzyczne tło śmierci starszej kobiety, która umiera samotnie na cmentarzu. Choć jej osamotnienie okazuje się pozorne, ponieważ jej odejściu towarzyszą wspominani w piosence bliscy pochowani na otaczającym ją cmentarzu. Śmierć staje się centralnym, szokującym wydarzeniem, które w odczuciu gracza burzy jego przyzwyczajenie do sprawowania kontroli nad awatarem, a także uderza w konwencjonalne traktowanie śmierci w grze jako oznaki własnego niepowodzenia. 


\section{Queers in Love at the End of the World}

Gra Anny Anthropy Queers in Love at the End of the World [2013] roku to intrygujący przykład radykalnej miniaturyzacji gry komputerowej. Gracz wciela się w postać towarzyszącą umierającej osobie i postawiony jest pod presją wybrania sposobu, w jaki spędzą ostatnią wspólnie przeżytą chwilę. Jednakże na swój wybór ma jedynie 10 sekund. Tyle właśnie trwa najkrótsza gra stworzona przez Anthropy, która jednocześnie jest wzruszającym doświadczeniem podejmującym tematykę śmierci bliskiej osoby.

Queers in Love... jest grą hipertekstową. Gracz postawiony jest przed możliwością podążania wieloma ścieżkami. Wychodząc od czterech podstawowych kategorii interakcji (relacje intymne, zmysłowe i romantyczne oraz rozmowa) autorka gry stawia odbiorcę przed koniecznością dokonania rzeczy niemożliwej, ponieważ podstawowe pytanie, jakie gracz zadaje sobie w trakcie rozgrywki, mogłoby brzmieć następująco: jakie zachowanie jest właściwe czy też najlepsze w tej tragicznej sytuacji?

Śmierć w grze jest bezwzględna, zarówno w wymiarze fabularnym (śmierci bliskiej osoby), jak i czasu rozgrywki. Konstrukcja gry wprowadza gracza w zakłopotanie: jak pogodzić błyskawiczne działania z powagą sytuacji? Użytkownik balansuje pomiędzy poświęceniem czasu na aktywne i produktywne wykorzystanie wszelkich możliwości rozgrywki a skupieniem się na intymnym charakterze sytuacji. Autorka nie wartościuje działań gracza, ponieważ w obliczu aktu umierania osoby bliskiej ludzkie zachowania posiadają różne motywy. Wartością tej gry jest stworzenie dzieła próbującego odwzorować nieuchwytność doświadczenia ostatnich chwil spędzonych z umierającym człowiekiem, w którym gracz konfrontowany jest z powagą i nieuniknionością śmierci. Istotną rzeczą jest także hipertekstowa forma konstrukcji gry, ponieważ dzięki niej Anthropy skoncentrowała fabułę na doznaniach zmysłowych i intelektualnych, jakie doznaje wirtualna para. W odróżnieniu od Passage i The Graveyard, które poprzez wizualizację stawiają gracza w pozycji obserwatora zdarzeń, w grze $Q u$ eers in Love... użytkownik skupia się na głębi doznań emocjonalnych, swoistej erupcji uczuć i namiętności, jakimi postaci gry pragną się ze sobą pożegnać. W tym kontekście gra Anthropy pobudza mnogość odczuć bohaterów gry, z którymi gracz wchodzi w interakcje. Jednocześnie stawia to grę w kontraście względem bezmiaru gier wideo, w których śmierć awatara traktowana jest jako norma i cząstka reguł.

\section{Podsumowanie}

Analizowane trzy gry ujmują śmierć w odmienny sposób niż nieartystyczne gry wideo, ponieważ akt umierania niejako na powrót zyskuje w nich kulturową rangę skandalu, czyli czegoś nienaturalnego i irracjonalnego. Przedstawiają one bogactwo 
znaczeń, jakie w artystycznych grach wideo zyskuje motyw śmierci, przy czym nie należy pomijać faktu, że śmierć w grze jest obserwowalna, zatem doświadczana z bezpiecznej, zdystansowanej pozycji gracza. O ile w Passage śmierć posiadała symboliczny wyraz w postaci nagrobka, a w The Graveyard ukazana została w wymiarze zatrzymania ruchu postaci (czyli w znaczeniu materialności ciała), to w Queers in Love... została ujęta jako koniec, nagłe zatrzymanie akcji gry, której towarzyszy wielość rozmaitych emocji. Każda gra prezentuje inny wymiar śmierci: symboliczny (Passage), materialny (The Graveyard) i emocjonalny (Queers in Love...).

Ważną kwestią są także niewielkie możliwości gracza. W każdej z analizowanych gier przestrzeń oraz czas rozgrywki są mocno ograniczone. Gracz nie może w Passage wybrać innej towarzyszki/towarzysza życia, w The Graveyard nie skręci w żadną z bocznych alejek cmentarza, a w Queers in Love... nie zastosuje własnej linii dialogowej. Z punktu widzenia intencjonalnego zamysłu twórców takie rozwiązania mają skupić gracza na konkretnych kontekstach, które są w określony sposób nacechowane emocjonalnie. Co istotne, awatary pozbawione są fabularnego osadzenia, dzięki czemu gry zyskują uniwersalny przekaz, ale kosztem utożsamienia się z bohaterami. Rozgrywka pozbawiona wstępnego przedstawienia akcji gry w określonych ramach fabularnych sprawia, że gracz interpretuje grę z pozycji zdystansowanej.

Cała konstrukcja gier sprowadza działania gracza do odtworzenia zawartych w nich opowieści. Warto przy tym dodać, że każda gra komputerowa pozwala tylko na takie działania, jakie zostały w nich zaprogramowane, jednak w trzech analizowanych artystycznych grach wideo możliwości gracza zostały sprowadzone do minimum. W tym tkwi problem terminologicznego ujęcia tego rodzaju gier, które często z racji znikomego potencjału ergodycznego traktowane są bardziej jako interaktywna narracja aniżeli gry komputerowe. Jednakże, ze względu na płynność granic między gatunkami nowych mediów, dywagacje natury terminologicznej nie wydają się na tyle istotne, aby nie uznawać analizowanych w artykule dzieł za gry wideo.

Zauważyć należy, że wykorzystanie motywu śmierci w artystycznej konwencji gry komputerowej wykracza poza pojęcie widowiskowej śmierci jako normy [por. Kuligowski i Zwierzchowski 2004, 9], co charakterystyczne jest dla rozrywkowych gier wideo. Śmierci zostaje nadane znaczenie pogłębione emocjonalnie, dzięki czemu użytkownik gier artystycznych doświadcza nowych, odmiennych wrażeń. Konfrontacja $z$ irracjonalnością śmierci zachęca gracza do przemyśleń nie tylko natury eschatologicznej, ale także do refleksji nad własną postawą jako użytkownika 
medium ergodycznego oraz nad wartościami zawartymi w grach komputerowych. Niekonwencjonalna struktura gry sprawia, że gracz bierze udział w metadyskursywnej, wieloznacznej grze wykraczającej poza schematy, do których przyzwyczajają swoich użytkowników nieartystyczne gry wideo.

\section{Bibliografia}

Aarseth, Espen. 2013, Ontology, [w:] Mark J. P. Wolf, Bernard Perron (red.), The Routledge Companion to Video Game Studies, New York-London: Routledge, s. $484-492$.

Ariès, Philipe. 2011, Człowiek i śmierć, przeł. Eligia Bąkowska, Warszawa: Aletheia.

Ariès, Philipe. 1993, Śmierć odwrócona, przeł. Jakub M. Godzimirski, w: Stanisław Cichowicz, Jakub M. Godzimirski (red.), Antropologia śmierci. Myśl francuska, Warszawa: PWN, s. 227-283.

Bauman, Zygmunt. 1995, Ciało i przemoc w obliczu ponowoczesności, Toruń: Uniwersytet Mikołaja Kopernika.

Czarny, Janusz. 1999, Osoba ludzka w umieraniu i śmierci (ujęcie personalistyczne), w: Bożena Płonka-Syroka (red.), Moralny wymiar choroby, cierpienia i śmierci, Wrocław: Arboretum, s. 25-32.

Gorer, Geoffrey. 1955, The Pornography of Death, „Encounter”, October, online: <http://www.unz.org/Pub/Encounter-1955oct - 00049> [dostęp: 20.09.2014], s. 49-52.

Juul, Jesper, 2011, Half-Real. Video Games between Real Rules and Fictional Worlds, Cambridge-London: The MIT Press.

Kuligowski, Waldemar, Zwierzchowski, Piotr. 2004, Pokażę ci, jak się umiera, w: Waldemar Kuligowski, Piotr Zwierzchowski (red.), Śmierć jako norma, śmierć jako skandal, Bydgoszcz: Akademia Bydgoska, s. 7-11.

Lenne, Gérard. 2002, Śmierć w kinie, tłum. Tadeusz Szczepański, w: Stanisław Rosiek (red.), Wymiary śmierci, Gdańsk: Słowo/Obraz Terytoria, s. 219-226.

Majkowski, Tomasz Z. 2011, Gry wideo i kultura autentyczności, „Homo Ludens” nr 1(3), s. 95-102.

Sterczewski, Piotr. 2016, Ta gra i takjest głupia, „Dwutygonik”, maj, online: <http://www. dwutygodnik.com/artykul/6556-ta-gra-i-tak-jest-glupia.html> [dostęp: 19.05.2016]. 
Ludografia

2015, Inc., 2002-, Medal of Honor [PC], USA: Electronic Arts.

Anthropy Anna, 2013, Queers in Love at the End of the World [PC, gra online], USA:

Anna Anthropy (grano 20 czerwca 2014).

Bethesda Softworks, 1994-, The Elder Scrolls [PC], USA: Bethesda Softworks.

Black Isle Studios, 1999, Planescape: Torment [PC], USA: Interplay Entertainment.

Blizzard Entertainment, 2012, Diablo III [PC], USA: Blizzard Entertainment.

Blizzard North, 2000, Diablo II [PC], USA: Blizzard Entertainment.

Cellar Door Games, 2013, Rogue Legacy [PC], Kanada: Cellar Door Games.

Maxis, 2000, The Sims [PC], USA: Electronic Arts.

Epic Games, 1999, Unreal Tournament [PC], USA: GT Interactive.

id Software, 1999, Quake III: Arena [PC], USA: Activision.

Konami, 1987, Contra [Nintendo Entertainment System], Japonia: Konami.

Namco, 1985, Battle City [Nintendo Entertainment System], Japonia: Namco.

New World Computing, 2002, Might and Magic IX [PC], USA: The 3DO Company.

Nintendo, 1985, Super Mario Bros. [Nintendo Entertainemnt System], Japonia: Nintendo.

Rockstar North, 1997-, Grand Theft Auto [PC], USA: Rockstar Games.

Rohrer Jason, 2007, Passage, [PC], USA: Jason Rohrer.

Tale of Tales, 2008, The Graveyard [PC], Belgia: Tale of Tales.

\section{Summary}

The uniqueness of the experience of death in art video games

Video games present different meanings of death than those conditioned by social and cultural contexts. Most games treat the motif of death instrumentally. Therefore, death is usually a norm and a rule in typical video games. However, art games present a different sense of death, one that defies its conventional meanings. The article analyses the different presentations of death in three art games: Passage (Rohrer, 2007) The Graveyard (Tale of Tales, 2008) and Queers in Love at the End of the World (Anthropy, 2013). These productions prove that video games are an excellent medium to offer players a deep emotional experience, which can also encourage taking a fundamental and more profound reflection on the meaning of life and death.

Keywords: art games, death, video games, Jason Rohrer, Anna Anthropy, Tale of Tales 
mgr Andrzej Strużyna - kulturoznawca, doktorant Wydziału Filologicznego Uniwersytetu Opolskiego. Członek zwyczajny Polskiego Towarzystwa Badań Gier. Interesuje się teorią nowych mediów, sztuką nowych mediów, kulturą popularną, a także historią, teorią i krytyką gier komputerowych. Szczególnym zainteresowaniem darzy artystyczne gry wideo.

mgr Hanna Strużyna - literaturoznawczyni, serbistka, doktorantka Wydziału Filologicznego Uniwersytetu Opolskiego. Interesuje się nowymi mediami, kulturą popularną i współczesną literaturą bałkańską. Zajmuje się badaniem powieści graficznych bałkańskich autorów. 